International Journal of Linguistics, Literature and Translation (IJLLT)

ISSN: 2617-0299 (Online); ISSN: 2708-0099 (Print)

DOI: $10.32996 / \mathrm{jjllt}$

Journal Homepage: www.al-kindipublisher.com/index.php/ijllt

IJLLT

\title{
Paul Gilroy's The Black Atlantic Quarter a Century Later: Cultural Implications of African Diaspora's Revision of Modernity
}

Lahoussine Hamdoune

Department of English Studies, Faculty of Languages, Arts, and Human Sciences, Ibn Zohr University Campus, Ait Melloul

Corresponding Author: Lahoussine Hamdoune, E-mail: I.hamdoune@uiz.ac.ma

\section{ARTICLE INFORMATION}

Received: November 08, 2020

Accepted: December 01, 2020

Volume: 3

Issue: 12

DOI: 10.32996/ijlt.2020.3.12.6

\section{KEYWORDS}

Black Atlantic; culture; diaspora; hybridity; memory; modernity; movement; nation

\section{ABSTRACT}

In his seminal book The Black Atlantic: Modernity and Double Consciousness (1993) Paul Gilroy traces an account of the Black diaspora as a cosmopolitan, historical and cultural Atlantic phenomenon that challenges and corrects Modern construction of 'culture,' 'nation,' 'history,' and ultimately 'identity.' Although the book was conceived quarter a century ago, it still continues to influence Black Studies, Migration Studies, Postcolonial Studies, and Diaspora Studies. The present paper intends to shed light and reflect on the two most influential aspects of Gilroy's book today. One such aspect is Gilroy's exploration of Black Atlantic histories of (criss)crossing, migration, interconnection, travel, and exile-- together with the form, content, and performance of diasporic expressive forms-- to revisit the tradition of Modernity and Enlightenment rationality. The other aspect, following from the first, is that while interrogating "national," "nationalistic," and "ethnically absolutist paradigms" such as "Englishness," "Africanism" and "tradition," he highlights cultural hybridity, transnationality, and memory. By so doing he subverts modernity's racialized monolithic definition of 'culture' and 'nation (state)' along with its construction and association with teleological historiography.

\section{Introduction}

In his seminal The Black Atlantic: Modernity and Double Consciousness (1993), Paul Gilroy traces an account of the Black diaspora as a cosmopolitan, historical and cultural Atlantic phenomenon that challenges and corrects Modern construction of 'culture,' 'nation,' 'history,' and ultimately 'identity.' Gilroy's notion of the Black Atlantic roughly refers to a particular counterculture of modernity that rests on a peculiar 'double consciousness' inherent in blackness. Such 'double consciousness' is a form of cultural categorization that is simultaneously modern and antithetical to the monologic idea of the West. The present work is an attempt to demonstrate that the experience which Gilroy labels "black Atlantic culture" turns out to become a diasporic African contribution to the 'revision' of those racialized essentialist views of 'culture,' 'history,' and 'nation' constructed by Modernity. Though The Black Atlantic was conceived more than quarter a century ago, the book has continued to influence recent interpretive and descriptive investigations of issues of modernity, migration, identity, and transnationality and the dramatization of these issues in global literatures and arts. To lay bare such an influence, the present work will outline and interpret the main tenets of what Gilroy considers the genuine contribution of African diaspora to the revision of modern definitions of 'culture,' 'nation,' and 'identity.' The core of Gilroy's proposition, to consider here, is that African diaspora has since the Middle Passage continued processes of movement, cultural creation and exchange in and across the Atlantic rim and the northern hemisphere, processes being located inside modernity but simultaneously subverting modernity's racialized hegemonic character. Besides, Gilroy's idea of the Black Atlantic concept's interrogation of Modern rationality and its constitution of history and aesthetics will be examined. In the process, it will be demonstrated that through processes of "hybridity" and "movement," African diaspora around the Atlantic basin has been refuting appeals to "homogenization," "origins," and "tradition." As such, the Black Atlantic has ultimately conceived the entities Gilroy terms a "counterculture" and a "counterhistory" of Modernity. While drawing attention to the cultural implications of the history of African diaspora's movement and interaction across the Atlantic, Gilroy's cultural and critical model of the 'Black Atlantic'

\section{K C AL-KINDI CENTER \\ R D PEVELOPMENT Your gateway to world-closs reearch}

Published by Al-KindiCenter for Research and Development. Copyright (c) the author(s). This is an open access article under CC BY license (https://creativecommons.org/licenses/by/4.0/) 
actually cherishes the positives of recent experiences of people's mobility and processes of cultural syncretism and transnationalism.

\section{Diasporic Africans' (re)construction of 'identity' as always 'in transit' 2.1. Black Atlantic Mobility as subversive of Cultural Nationalism}

The Black Atlantic is a form of critical analysis of modernity that interrogates the centrality of racism and the whole notion of race in it. By offering a theorization of creolization, hybridity and cultural mutation, Gilroy's model undermines that modern racialized and overhomogenized construction of cultural identity that has influenced most Africanist nationalist discourses. As Gilroy (1993) points out, the Black Atlantic "provides a means to reexamine the problems of nationality, location, identity, and historical memory" (p. 16) and arises from a "desire to transcend both the structures of the nation state and the constraints of ethnicity and national particularity" (p. 19). Central to such analysis is a rejection of "the suggestion that cultural fusion involves betrayal, loss, corruption, or dilution" (p. 144). As Gilroy stresses, hybridity, or cultural intermixture, is to be recognized instead as "not the fusion of two purified essences but rather a meeting of two heterogeneous multiplicities that in yielding themselves up to each other create something durable and entirely appropriate to troubled anti-colonial times" (p. 144). Gilroy maintains at the outset of his book that "all blacks in the West . . . stand between (at least) two great cultural assemblages," namely those of nationality and ethnicity (p. 1). These, in turn, are closely connected to ideas about authenticity and cultural integrity so that the identity of 'black' or 'white' people is formed as pure, fix, and unrelated, or even antithetical, to each other. While this situation is inconsistent with the history of the Black Atlantic, it is an outcome of modernity in that it maintains that characteristically modern construction of cultural nationalism on the basis of a purified conception of culture.

1. The history of the black Atlantic is a model that subverts the essentialist perceptions of cultural identity and nationality. Such history, as Gilroy advances, "yields a course of lessons as to the instability and mutability of identities which are always unfinished, always being remade" (p. xi). Not only does this perspective underscore the "pattern of movement, transformation, and relocation" (p. xi) together with "the inescapable hybridity and intermixture of ideas", but it also constitutes the "awareness of the African diaspora as a transnational and intercultural multiplicity" (p. 195). Gilroy underscores, moreover, the Black Atlantic as a "web of diaspora identities and concerns" that should not be conflated with projects of "building an ethnically particular or nationalist cultural canon" (p. 218). Instead, at issue is a theorization of "the inescapability and legitimate value of mutation, hybridity, and intermixture en route to better theories of racism and of black political culture than those so far offered by cultural absolutists of various phenotypical hues" (p. 223).

2. This perception points to an 'alternative discourse' of cultural belonging that goes beyond the myth of what Stuart Hall calls "blood and soil." This alternative is accounted for by the image of moving ships. As Gilroy explains,

I have settled on the image of ships in motion across the spaces between

Europe, America, Africa, and the Caribbean as a central organising symbol for

this enterprise and as my starting point. The image of the ship - a living,

microcultural, micro-political system in motion - is especially important for

historical and theoretical reasons ... Ships immediately focus attention on the

middle passage, on the various projects for redemptive return to an African

homeland, on the circulation of ideas and activists as well as the movement of

key cultural and political artifacts: tracts, books, gramophone records, and

choirs." (p. 4)

This image invokes narratives and histories of movements of Africans across the Atlantic since the Middle Passage. Yet, the notion of "roots/routes" is not deployed as a dichotomy whose two sides stand in a sharp oppositional relation. Rather, they are in a relational one in which the first side is part of the second while retaining its difference from it. Besides, the image of "moving ships" refers to the trespassing of geographical boundaries and cultural boundaries, a matter he further illustrates in claiming that the term "diaspora"

opens up a historical and experiential rift between the locations of residence and the locations of belonging . . . Consciousness of diaspora affiliation stands opposed to the distinct complexity of nation-states. Diaspora identification exists outside of and sometimes in opposition to the political forms and codes of modern citizenship. (p.124) 


\subsection{Syncretic cultures: The Black Atlantic's influences and impact}

Gilroy's focus on movements actually summons other views on diaspora and cultural identity that have influenced Gilroy's model or have been influenced by it. One such view is Stuart Hall's eminent observation that "identities are about questions of using the resources of history, language and culture in the process of becoming rather than being: not 'who we are' or 'where we came from,' so much as what we might become, how we have been represented and how that bears on how we might represent ourselves" (1996, p.4). Hall's seminal paper on "Cultural Identity and Diaspora," in turn, stresses continuity and discontinuity, similarity and dissimilarity. In it Hall declares that "[t]he diaspora experience as I intend it here is defined, not by essence or purity, but by the recognition of a necessary heterogeneity and diversity; by a conception of 'identity' which lives with and through, not despite, difference; by hybridity" (Mirzoeff, 2000, p.31). No less influential has been James Clifford's essay on diaspora, which incorporates a dialogue with Paul Gilroy's formulations of African diaspora across the Atlantic in The Black Atlantic. Clifford proposes that "it is not possible to define 'diaspora' sharply, either by recourse to essential features or to privative oppositions. But it is possible to perceive a loosely coherent, adaptive constellation of responses to dwelling-in-displacement." He suggests that "Diaspora cultures . . . mediate, in a lived tension, the experiences of separation and entanglement, of living here and remembering/desiring another place" (Clifford, 1997, p. 254; p. 255). Clifford contends, moreover, that

Diaspora consciousness is . . constituted both negatively and positively. It is constituted negatively by experiences of discrimination and exclusion. ... Diaspora consciousness is produced positively through identification with worldhistorical cultural/political forces, such as "Africa" or "China." The process may not be as much about being African or Chinese as about being American or British or wherever one has settled, differently. . . . diasporic consciousness "makes the best of a bad situation." Experiences of loss, marginality, and exile (differentially cushioned by class) are often reinforced by systematic exploitation and blocked advancement. (1997, pp. 256-257)

Akin to Hall and Clifford, Gilroy stresses the necessity that in their grappling with issues of identity, communities should not only consider their being, but their becoming as well. This they ought to do by looking on how they become what they are and where they are heading -- an idea he has expressed in his famous call to ask not the question "Where you are from" but rather, "Where are you at?" (1991, p. 3).

Through the image of the black Atlantic as a chronotope moving ship, endorsed by his exploration of W. E. B. Du Bois' concept of "double-consciousness," Gilroy calls for a rethinking of "ethnically absolutist paradigms" such as "Englishness," "Africanism," and "tradition." Actually, the concept of "double-consciousness" as coined by W.E. B. Du Bois (1903) comes in the Du Boisian of-cited passage:

After the Egyptian and Indian, the Greek and Roman, the Teuton and Mongolian, the Negro is a sort of seventh son, born with a veil, and gifted with second-sight in this American world, -- a world which yields him no true selfconsciousness, but only lets him see himself through the revelation of the other world. It is a peculiar sensation, this double-consciousness, this sense of always looking at one's self through the eyes of others, of measuring one's soul by the tape of a world that looks on in amused contempt and pity. One ever feels his twoness, -- an American, a Negro; two souls, two thoughts, two unreconciled strivings; two warring ideals in one dark body, whose dogged strength alone keeps it from being torn asunder. (p. 34)

Revisiting Du Bois's "double-consciousness," Gilroy (1993) criticizes "Afrocentric" theories clinging to "the overintegrated conceptions of pure and homogeneous culture" (p. 31) for overlooking the influence on groups of African diaspora of that relentless movement of people and cultures throughout the Atlantic history since the sixteenth century. As Gilroy sees it, these theories deploy, rather than challenge, essentialist Modern views of culture which underline fixity, origins, or "roots," rather than mobility and transformation, or "routes." To his mind, "[m]arked by its European origins, modern black political culture has always been more interested in the relationship of identity to roots and rootedness than in seeing identity as a process of movement and mediation that is more appropriately approached via the homonym routes" (p. 19). More explicitly put, this stance leveled at the Pan-African cultural nationalism emanates from its mirroring, rather than subversion, of Western Modernity and its by-product of European colonialist racial discourse constructing cultural difference on those ideas of racial authenticity and tradition being rooted in theories of race.

This stand is actually redolent of revisionary voices in Postcolonial and Black studies. For example, in her critique of postcolonial discourse in her seminal essay "Can the Subaltern Speak?", Gayatri S. Spivak emphasizes that oppositional discourses that rely on essentialized identities tend to mirror the structures of the dominant discourse rather than challenge them: "the 'subject' implied by the texts of insurgency can only serve as a counterpossibility for the narrative sanctions granted to the colonial 
subject in the dominant groups" (Ashcroft et. al., 2003, p. 28). In the same vein, Anthony Appiah (1992) levels a similar criticism at African and Pan-African nationalism, pointing out that the very categories of race and cultural nationalism are actually the product of European colonialism, which subjects the racialized natives to an imaginary identity category, contrasting sharply with the White civilized Other. Modernity actually constitutes and supports the discourse of nation through cultural particularities of traditions, customs, and values. To borrow Appiah's words, "nativism constructs national particularities, fetishizing the customs, folklore and vernacular, turning them into a 'culture,' that is, in fact, an artifact of Western modernity" (1992, p. 60).

Gilroy would further return to and endorse the idea that identities are syncretic and changing, an idea he associates with the "routes" in his book. He would, later on, adamantly reiterate his assertion that identity is mistakenly conceived to exist "in the neatly bounded, territorial units where true hand authentic culture could take root under the unsentimental eye of ruthlessly eugenic government" $(2000$, p. 62). As there is no accuracy to the existence of some racial essence or essential heritable characteristics and specific geographical space for a specific race, the significance of "roots/routes" undermines those rigid dichotomous conceptions of culture and history grounded in Modernity and ultimately informing, as Appiah (1992, p. 60) points out, both Eurocentrism and its reversed version of Afrocentrism.

\section{Black Atlantic intellectuals' revision of 'racialized' Modernity}

Though Gilroy considers masses of Black Atlantic diaspora true producers of hybrid vernacular cultural products and marked representatives of mobile communities, he shows, in my viewpoint, a special concern for two categories of intellectuals. The first consists of those thinkers and creative writers who self-consciously interrogated Modernity or experienced travel, the category labeled here 'conventional intellectuals'. The second, I term 'unconventional intellectuals,' involves those musicians and singers who actually voice the same cultural and political concerns as the caste of 'conventional intellectuals,' but are not conventionally viewed as genuine 'intellectuals.'

\subsection{The black Atlantic 'Conventional intellectuals" revision of Modernity}

In his examination of the works of 'conventional' intellectual black writers such as Frederick Douglass, Martin Delany, W. E. B. Du Bois, and Richard Wright, Gilroy aims to show these intellectuals' mobility across the Atlantic, their ambivalent position as to Modernity, and - in the case of contemporary authors like Toni Morrison and others - their grappling with issues of memory and history by developing a "slave sublime" that attempts to represent the "unspeakable" experience of slavery and its terror.

First, black Atlantic intellectuals challenge the ideas of 'nation(ality)' and 'origins' through that 'transformation' resulting from their travel or exile experiences. According to Gilroy, sojourning in Europe and engaging therein with European philosophy played a decisive role in shaping the personal and political sensibilities of black figures like Du Bois and Wright. Du Bois is a model that Gilroy markedly highlights in this regard because, first, his travel experiences "raise in the sharpest possible form a question common to the lives of almost all these figures who begin as African-Americans or Caribbean people and are then changed into something else which evades those specific labels and with them all fixed notions of nationality and national identity" (p. 19). For another thing, 'mobile' black Atlantic intellectuals of Du Bois' ilk generally "articulate a desire to escape the restrictive bonds of ethnicity, national identification, and sometimes even 'race' itself . . . [because] their relationship to the land of their birth and their ethnic political constituency was absolutely transformed" (p. 19).

Though there is much accuracy to the claim that black Atlantic intellectuals and artists' stay in Europe produces intellectual and political transformations that challenge "ethnic absolutism" and beliefs in close borders, Gilroy overlooks three major givens. One is that while focusing on Europe, he seems to undervalue other spaces of intellectual and political interaction that are no less significant in the construction of 'hybrid identities.' Advancing a corrective to Gilroy's reading, Laura Chrisman (2003) points out that he should have as well put due emphasis on the "intellectual, political and cultural cross-fertilisation of black America with the Caribbean and Latin America; with proletarian and socialist US cultures; with Third-World liberationist thought" (p. 80). She additionally notes that "a way to counter the problematic racial purism of Afrocentrism might be to emphasise and explore the significance of mixed-race intellectuals and their cultural texts" (p. 80).

The second problem is that, by underrating, say, the late Du Bois in his African exile, latent implications of such Duboisian experience for a different understanding of cultural and intellectual metissage or postcolonial African nation state are unfortunately not considered in The Black Atlantic. Gilroy, for example, disregards, as Ryan Jobson notes, "the tangible connection between Du Bois and the African continent that grew into his close personal relationship with Ghanaian President Kwame Nkrumah, adoption of Ghanaian citizenship, and the development of Du Bois's Pan-African consciousness" (2009, p. 
8). Du Bois, Jobson further adds, plainly supported Pan-Africanism, a fact to be seen in his "The Pan African Congresses: The Story of a Growing Movement," a text outlining "the need for Pan-African unity and the common socioeconomic struggle that exists across the diaspora" (8). Du Bois's Pan-Africanism suggests those aspects of the "Africanist discourse" that Gilroy is set out to criticize. Yet, that issue is not invoked in his book in relation with Du Bois's thought. Jobson is right, in this respect, in advancing that

Du Bois expresses a Garvey-esque call for diasporic unity, which should not be dismissed as a superfluous change of opinion. In the same way that Du Bois's early leanings were influenced by his education in Europe, so were his later views, following his first-hand experiences with the African continent. $(2009,8)$

The third problem in Gilroy's reading of black intellectuals movement across the Atlantic is that such a reading might imply that Africa, because consistently associated in The Black Atlantic with "roots," has neither produced nor received diasporic intellectuals worth of consideration. For one thing, he totally overlooks marked and genuine mobile African intellectuals, especially from francophone Africa, such as Sembène Ousmane, who are largely known for both their mobility, their sojourn in Europe, and their immense contribution to Postcolonial Studies and what turns out to be labeled Migration Studies. For another, both Du Bois and Wright actually supported the Pan-Africanism advanced by Postcolonial African and Caribbean intellectuals and leaders. Both, in fact, influenced and were influenced by the likes of Aimé Cisaire, Léopold Sédar Senghour, and Alioune Diop. Yet, Gilroy clearly overplays the disconnection of Wright with African Pan-Africanism, just as he does in the case of Du Bois, presumably because he barely summons the influence of African intellectuals on each other and on their African-American pals and because he understates the Pan-Africanist content in the writings of Du Bois and Wright. Gilroy suggests, indeed, that "Wright shared the central themes of the Congress of Negro Writers and Artists, held in Rome in 1959, which 'were the unity of 'Negro culture' and the creative political responsibilities which fell upon the caste of black intellectuals responsible for both demonstrating and reproducing that unity"' (1993, p. 195). Confirming this point, Babakar M'Baye (2009) points out that Wright had a major role in the development of Présence Africaine and Negritude. However, despite his views on the Pan-Africanist ideas and concepts of culture and race that Senghor and Diop expressed in their convention speeches, it is his view on the position of the African in Modernity that makes Wright apart from Senghor and Diop. Diop, for example

envisioned a world in which Blacks of both sides of the Atlantic would overcome the painful cost of colonial history through recognition of their priceless role of major contributors in the modern world. Diop's valuation of Black modernity is apparent in his inaugural speech at the 1956 Congress in which he urges Blacks of the United States, the Caribbean, and Africa to recognize their descendance from the same ancestors in spite of their diverse spiritual universes ... and contribute, like the Jews have done, to the emergence of an international and modern world in which people of all races could live together without reference to skin color. (2009, p. 33)

Wright, on the contrary, emphasizes the particularity of African-American experience and its location in Modernity. As M'baye notes,

Wright's resistance to the notion of shared Black cultures stemmed from his uncertain attitudes about Black unity which led him to privilege his African American experiences at the expense of those of his African contemporaries which he did not locate in modernity. He usually views Africans as mere victims of history who have no possibility of rebirth, unity, or harmony. (2009, p. 34)

The movement of Black Atlantic intellectuals across the Atlantic and their sojourn in Europe clearly engenders their transnationalism and their intellectual hybridity. Nevertheless, Gilroy has focused almost wholly on African-American intellectuals, and those of whom receiving his emphasis, namely Du Bois and Wright, actually supported to different degrees Pan-Africanism.

In addition to their mobility across the Atlantic and the related consequence of the assimilation of modern thought, Black Atlantic intellectuals wrestle with the representation of the Black Atlantic historical consciousness, a consciousness standing out by its character as a "syncopated temporality." The present, constantly being revisited upon by the memories of slavery and the Middle Passage, becomes broken. Though they actually assert the impossibility of accurately recovering a social past, Morrison and other imaginative writers, similar to musicians like James Brown, have developed the strategy Gilroy calls "slave sublime." In musical performances, this strategy involves silence, interruptions, shouting and many non-verbal aspects that undermine modern textuality. In narrative writing, writers such as Morrison have polished strategies and techniques that 
parallel and capture "slave sublime" as displayed in musical performances. Reopening the "space of death" through imaginative rewriting of memories of slavery in Morrison's narratives constitutes, as Gilroy argues, not a mere attempt to recuperate the terror and brutality of slavery, but a "syncopated" cultural critique of all "modernist progressivisms."

Black Atlantic form of "counterhistory" uncovers in two respects the "complicity of rationality with racial terror" (p. 213). On the one hand, this act brings to the fore that initial brutal confrontation with the African that Modernity inaugurated and sustained for centuries, supported by rationality and (racial) scientism. Gilroy points out in this vein that

[t]he desire to return to slavery and to explore it in imaginative writing has offered Morrison and a number of other contemporary black writers a means to restage confrontation between rational, scientific, and enlightened EuroAmerican thought and the supposedly primitive outlook of prehistorical, cultureless, and bestial African slaves (p. 220).

On the other hand, such a gesture subverts the contention that since racial slavery as a systematic practice precedes Modernity and Capitalism, it is definitely outside Modernity. By insisting on remembering the racial terror of slavery as embedded in Western Modernity since its initial confrontation with the African as (its) extreme 'Other,' African-Americans actually undermine racism. Reconstructing it, through memory, as a product, rather than an antecedent, of Western Modernity, they subvert the seeds of modern racism. This is a point Gilroy had made, quite before The Black Atlantic, in There Ain't No Black in the Union Jack (1987). In that book, he noted that racism "rests on the ability to contain Blacks in the present, to repress and to deny the past" (1987, p. 12). Returning once more to this idea, but reading it this time in AfricanAmerican literature, he comments on Morrison's Beloved (1987), a masterpiece imaginative rewriting of memories of slavery, pointing out that "[t]he misguided association of slavery with antiquity and precapitalist systems of production and domination is broken, but the break indicates the opportunity to reconceptualise so that capitalist racial slavery becomes internal to modernity and intrinsically modern" (p. 1993, 220; emphasis added).

By locating slavery inside Modernity, Morrison, redolent of many African-American creative writers, actually marks out blacks as "the first truly modern people" (p. 221). This subversive gesture is unequivocally expressed in an interview with Morrison quoted in The Black Atlantic. In it, Morrison advances that ". . . modern life begins with slavery. ... Black women had to deal with post-modern problems in the 19th century and earlier. These things had to be addressed by black people a long time ago: certain kinds of dissolution, the loss of and need to reconstruct certain kinds of stability. . . These strategies for survival made the truly modern person" (p. 221). Morrison's categorization of the African as the first "modern person" presupposes that African diaspora had grappled with the angst of Modernity long before the European was conscious of 'modern melancholy' largely due to social alienation and fragmentation. Yet, while Western 'modern melancholy' describes a rather individual state of 'self-conscious unhappiness' within the caste of the master, diasporic Africans' initial experience and consciousness of Modernity is rather a collective suffering resulting from slavery and its consequences of racial segregation and related economic deprivation. As to Morrison's claim that black women had to grapple with "postmodern problems" a century before Western men and women had to, it implies that the subaltern black women advanced, on the basis of 'race' and 'gender,' a critique of Modernity that would have been an early form of Postmodernism. They interrogated, that is, the principles of humanism, equity, and social justice being the main discursive enunciations of Modernity. It is as though those women's 'critique' of Modernity had involved what would be known in the Western academy as the "failures" of the "project of modernity," an issue to become, many decades later, a concern of postmodernist intellectuals such as Jürgen Habermas. But, whereas such a subaltern view, not indeed summoned by academicians, questions the 'humanism' and 'universalism' of Modernity, Postmodernist intellectuals of the ilk of Habermas do not generally interrogate those univocal European conceptions of universals, nor do they revisit the idea of historical progress, that is itself a construct of modernity, and its placing of the West as the center of history/civilization.

\subsection{Black Atlantic Musicians as 'Vernacular intellectuals'}

Gilroy's consideration of Black Atlantic musicians genuine "intellectuals" might sound rather unconventional. It challenges, to say the least, the idea of an automatic association of 'literacy' and 'intellectuality' at the heart of Antonio Gramsci's "organic intellectual." To begin with black Atlantic musicians' destabilization of Gramscian "organic intellectual" and their being considered actual "intellectuals" in the first place, an examination of an intellectual's functions and affiliations is worth undertaking. For Gramsci, the function or the role of modern "organic intellectuals" of the twentieth century is determined by class affiliation. Each class has a cadre of thinkers who originate from within it and are dedicated to voicing its positions, interests, and future within the nation state. In this respect, 
the working class ... is capable of developing from within its ranks its own organic intellectuals, and the function of the political party ... is that of channeling the activity of these organic intellectuals and providing a link between the class and certain sections of the traditional intelligentsia (qtd. in Farred, 2003, p. 4).

While the Gramscian concept, presupposing a high level of literacy, does not call upon the given of race or gender, it indeed links the political intervention of the "organic intellectual" to his/her activism within and through the party or union. Black Atlantic musicians and singers that Gilroy labels "intellectuals" and I call -- going by Grant Farred (2003) -- "vernacular intellectuals," are usually not activists within political parties or trade unions. Farred (2003) points out, therefore, that

[w] hat counts as an intellectual labor extends beyond the framework of The Prison

Notes-Gramsci's egalitarian terms in which the vernacular is a critique of the traditional/ organic intellectual, at once a recognition of Gramsci's inadequacies and a model that exceeds by incorporating within its framework, without eliding difference, the work of scholars such as [Stuart] Hall and [C. L. R.] James constructs intellectuals as those figures who represents more than the printed or spoken word of the educated middle class, the bourgeoisie, or the formally trained or the formally trained working-class intellectual. (p. 3)

Musicians and singers, viewed as 'vernacular intellectuals,' demonstrate a striking 'homology' differentiating the 'content' of Black Atlantic tradition. Music performers, in the vein of conventional intellectuals and imaginative writers, wrestle, in fact, with the same issues. Specifically, they grapple with the retrieval of a history of terror through remembrance; they attempt to establish the unity of the aesthetic, the political, and the ethical; they demonstrate Black Atlantic diaspora's ambivalent position as to Modernity.

If, for Hegel, cognitive and conceptual abstractions manifested in written language as textuality constitute the highest expression of human consciousness, Black music subsuming in one unit the aesthetic and the cognitive is, for Gilroy, a form that can capture even the ineffable. That which challenges textuality, that which conventional language cannot verbalize, is readily expressed through Black music as a representational art form. This Black vernacular expression is, according to Gilroy (1993), "a cipher for the ineffable, sublime, pre-discursive and antidiscursive elements in black expressive culture" (p. 120).To be sure, a "transcoding" and a "disguise expression" of the "unspeakable horror of the suffering caused by slavery" are prevailing in black music. These usually manifest themselves in form of stories of "terror and death" or "love and loss" (p.168). For Gilroy, African musical practices constitute a model of a tradition that preserves itself even as it continues to transform and change. Black music epitomizes therefore a tradition as an enduring "changing same" (p. 198). Of all black vernacular cultural expressions, music is by far the most telling in reopening the memory of slavery and the most eloquent in articulating "counterculture" 'inside' Modernity. Because it stands out as a "changing same," black music is essentially "hybrid." AfricanAmerican music, for example, is, according to Gilroy, a "cultural mutation" composed of the "creolization" of pre-modern African and modern American constituents. While this hybrid character demonstrates Black music's location both "inside" and "outside" of Modernity's aesthetics, it displays the position of the memory of slavery "within" modernity. This being the case, Afrocentrists' claims to the opposition between tradition and modernity and to the purity of an African tradition that precedes the Middle Passage, are not actually well-founded. These claims are, further, challenged by those acts of remembrance displayed in music, acts that are, as Gilroy notes, overwhelmed by the memory of slavery.

For Gilroy, Black music is a "prediscursive" and a "premodern" version of "antimodernity" because it advances through its "utopian contents," as demonstrated in the "stories of love and loss," a critical position that subverts rationality while underscoring utopian aspirations. Indeed, such utopian contents emanate from a Black Atlantic consciousness Gilroy terms "jubilee" (68; 212). It is this consciousness, Gilroy asserts, that motivates and justifies slaves' preference of death over bondage as can be seen in the slaves' going to the gallows singing, in Margaret Garner's killing of her child to spare her slavery, or in Fredrick Douglass's and other slaves' deadly fight against masters for emancipation-- even if that would cost their own lives. By examining these examples along with instances of songs involving stories of "love and loss," Gilroy shows, first, that the concept of "Jubilee" is used and called upon "to mark a special break or rupture in the conception of time defined and enforced by the regimes that sanctioned bondage" (p. 212). Gilroy's differentiation of Black Atlantic as a "counterhistory" is largely informed by the prevailing of this 'temporal consciousness' standing as another yet form of "syncopation" or "counterbeat" in Modern history. Second, these instances testify to the fact that while the concept of "jubilee" marks the 'agency' of the slave and thereof of the African (diaspora), it is "liberatory" "prediscursive" and "antidiscursive" all at once; for, 
on the one hand, "[t]he discourse of black spirituality which legitimizes these moments of violence possesses a utopian truth content that projects beyond the limits of the present" (p. 68). On the other hand, "the repeated choice of death rather than bondage articulates a principle of negativity that is opposed to the formal logic and rational calculation characteristic of western modern thinking and expressed in the Hegelian slave's preference for bondage rather than death" (p. 68). Though "jubilee" has literally a temporal aspect as well as a religious aspect to it, it is essentially a critical form of intervention that is informed by the Black vernacular culture. As manifested in the content of Black Atlantic music and in the experience of slavery, "jubilee" has actually largely functioned as an interventional strategy.

By (re)activating the memories of slavery, usually through music, Black Atlantic masses, redolent of their slave ancestors, articulate a refusal of Modernity's categorical separation of the spheres of aesthetics, ethics, politics and epistemology. As Gilroy suggests,

[t]he memory of slavery, actively preserved as a living intellectual resource in their expressive political culture, helped them to generate a new set of answers to this enquiry. They had to fight - often through their spirituality - to hold on to the unity of ethics and politics sundered from each other by modernity's insistence that the true, the good, and the beautiful had distinct origins and belong to different domains of

Knowledge. (p. 39)

James Baldwin's famous pronouncement, "history is our burden and music our witness," is replete with salient implications in this respect. Actually, Black music carries within it the burden of Black Atlantic history; if such music is not the very memory of African diaspora, then it, at least, articulates in the most eloquent fashion that history. In doing this it marks itself as a "changing same," an entity that is always itself but simultaneously always alters, appearing in diverse forms and styles mutilating, in turn, while assimilating other forms and elements. As such it truly undermines, largely through its form, claims to cultural "particularism," black and white, and largely through its utopian content, Modernity's rationality and the resulting separation of the aesthetic and the political.

\section{Conclusion}

The present work has attempted to demonstrate that the experience Gilroy labels "black Atlantic culture" turns out to become a relentless diasporic African contribution to the 'revision' of those racialized essentialist views of 'culture,' 'history,' and 'nation state' constructed by Modernity and influencing recent discourses of nationalism and cultural particularism. This genuine contribution has since continued through cultural creation and exchange in the North hemisphere as well as through relentless movement, across the Atlantic, of people-laymen and women, intellectuals, imaginative writers, musicians, and others. By interrogating Modern rationality and its constitution of history and aesthetics, by underscoring "hybridity" and "movement," and thus refuting appeals to "homogenization," "origins," and "tradition," African diaspora's experience in the Black Atlantic region has ultimately conceived the entities Gilroy terms a "counterculture" and a "counterhistory" of Modernity. Despite these influential ideas, Gilroy's focus, from which his conclusions follow, is limited to the Anglophone Atlantic, or rather, to the American and, to a lesser extent, to black British branches of the African diaspora. As such, while his ideas highlighting people's mobility, cultural hybridity, and transnationalism have impacted Black Studies, Migration Studies, Diaspora Studies, and Postcolonial Studies, his scope has missed several interesting zones of cultural interaction and historical encounters such as the Mediterranean. Indeed, the Mediterranean basin is an outstanding crossroad in which sub-African, North African, European, and Caribbean intellectuals, artists, and work-seeking immigrants meet and interact. The fact that Postcolonial Studies, interacted with what would later be labeled Black Studies, emerged in this cultural zone, is pregnant with historical and cultural implications. Frantz Fanon, Leopold Sénghour, and Albert Memi recharted a connection between the Atlantic and the Mediterranean that Gilroy has totally overlooked and future research should explore.

\section{About the Author}

Lahoussine HAMDOUNE (Ph. D) is Assistant Professor at the Department of English Studies, Faculty of Languages, Art, and Humanities, Ibn Zohr University, Ait Melloul, Morocco. He has a Ph.D in African-American Studies from the Faculty of Letters and Humanities, Ibn Zohr University, Morocco. In addition to African-American Studies, his research interests involve Cultural Studies, Postcolonial Studies, and TEFL. 


\section{References}

[1] Ain, T. (1987). t No Black in The Union Jack: The Cultural Politics of Race and Nation.

[2] Appiah K., Anthony. (1992). In my father's house. New York: Oxford University Press.

[3] Clifford, J. (1997). Routes: Travel and translation in the late twentieth century. Harvard University Press.

[4] Ashcroft, B., Griffiths, G., \& Tiffin, H. (Eds.). (2003). The post-colonial studies reader. Taylor \& Francis.

[5] Atlantic, B. (1993). Modernity and Double Consciousness. Gilroy, 114, 116-118.

[6] Chakravorty, G. (1999). Spivak" Can the subaltern speak?". Cary Nelson and Lawrence Grossberg (Urbana: University of Illinois Press, 1988), 271, 313.

[7] Chrisman, L. (2018). Journeying to Death: Paul Gilroy's The Black Atlantic. In Postcolonial contraventions. Manchester University Press.

[8] Bois, D., \& Burghardt, W. E. (1903). The souls of black folk: Essays and sketches. Chicago: McClurg \& Co.

[9] Farred, G. (1997). What's my name?: Black vernacular intellectuals. U of Minnesota Press.

[10] Gilroy, P. (2000). Against race: Imagining political culture beyond the color line. Harvard University Press.

[11] Gilroy, P. (1991). It ain't where you're from, it's where you're at... The dialectics of diasporic identification. Third text, 5(13), 3-16.

[12] Hall, S. (1996). New ethnicity. D. Morley y K. Sing. Chen (eds.): Stuart Hal. Critical Dialogues in Cultural Studies, London-New York, Routledge.

[13] Jobson, R. (2009). Postmodernism and Transnationalism in the Black Atlantic. In Situ, 1(1), 2.

[14] Mirzoeff, N. (Ed.). (2000). Diaspora and visual culture: representing Africans and Jews. Psychology Press.

[15] M'Baye, B. (2009). Richard Wright and African francophone intellectuals: a reassessment of the 1956 Congress of Black Writers in Paris. African and Black Diaspora: An International Journal, 2(1), 29-42. 